MAGNARTO प्राम

(4)

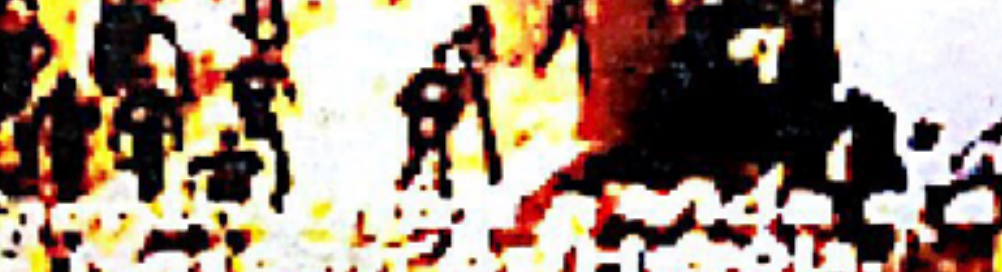

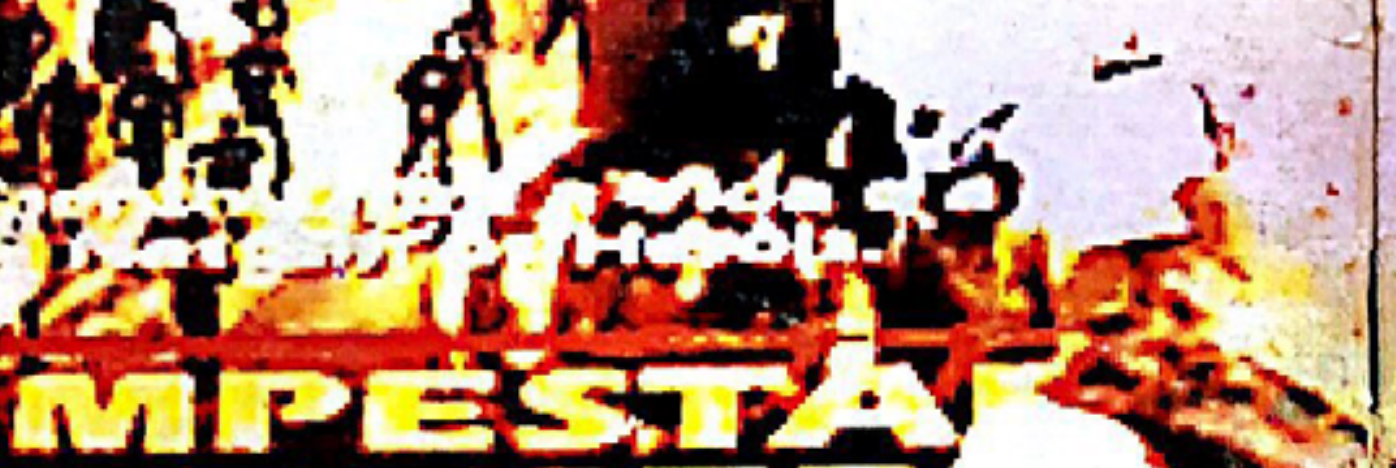

$2 D S T=15$

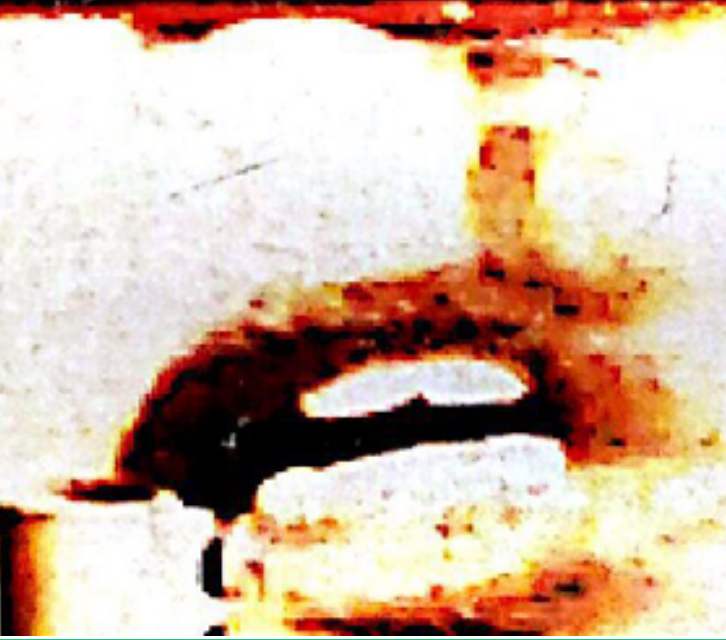

A estética do imaginário no cinema

Demian Garcia e André A. Medeiros P. 94

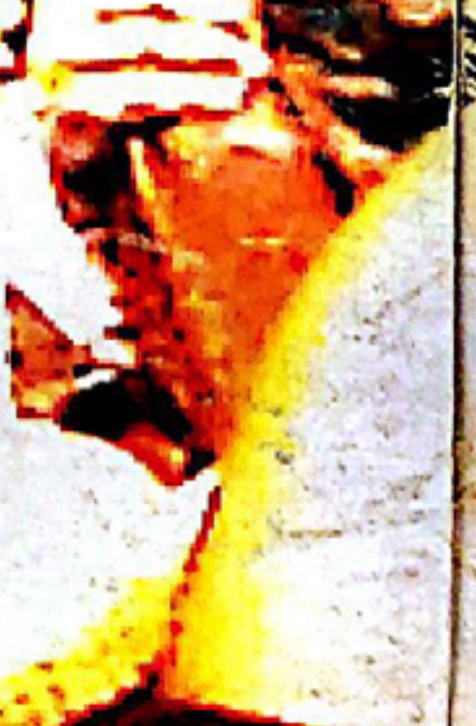

$+$

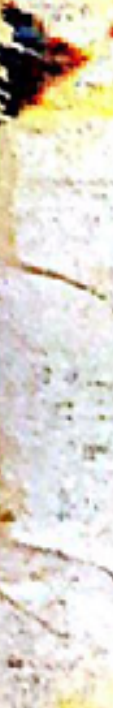

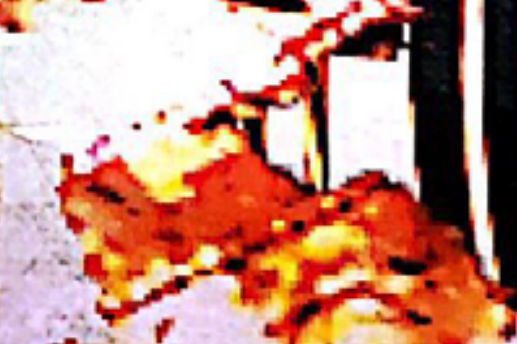

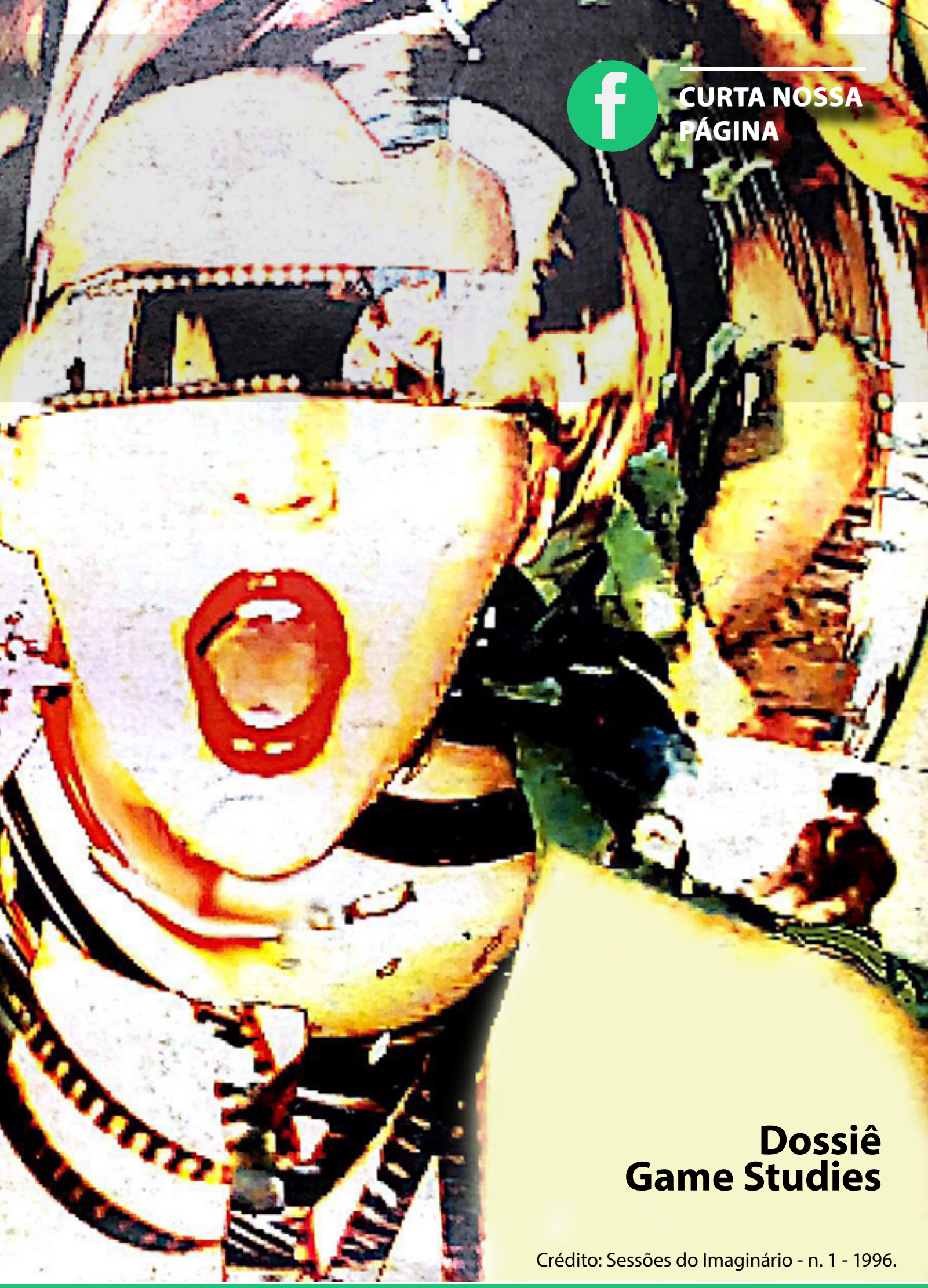

Materialidades fílmicas, magia e montagem

Ednei de Genaro

P. 112

Videogames, transgressão e criatividade no Brasil

Emmanoel Ferreira 


\section{Narrativas do outro: imagens e mediações complexas em "Fuocoammare"}

\author{
Narratives of the other: complex \\ images and mediations in \\ "Fuocoammare"
}

\section{Resumo}

Este trabalho busca lançar uma abordagem crítica sobre obras audiovisuais centradas na alteridade, tomando como objeto de estudo - documentário Fogo no Mar (Fuocoammare, Gianfranco Rosi, 2016) e sua representação acerca das interações entre os moradores da ilha italiana de Lampedusa e os refugiados do Norte da África e do Oriente Médio. Para isso, autores dos estudos sobre imagem, cinema, mídia e cultura e das ciências da linguagem são usados para compreender a mediação do outro operada a partir do testemunho, da construção de polos opositivos e de um regime de imagens pautado pela sensorialidade e pelo realismo.

\section{Palavras-chave}

Alteridade; representação; mediação; imagem complexa; documentário.

\section{Abstract}

This work seeks to launch a critical approach to audiovisual works focusing on otherness, taking as its object the documentary Fogo no Mar (Fuocoammare, Gianfranco Rosi, 2016), and its representation of the interactions between the inhabitants of the Italian island of Lampedusa and the refugees from North Africa and the Middle East. For this purpose, authors of the studies on image, cinema, media and culture and the language sciences are used to understand the mediation of the other operated from the testimony, the construction of opposing poles and a regime of images guided by sensoriality and realism.

\section{Keywords}

Alterity; representation; mediation; complex image; documentary.

154 PORTO ALEGRE | v. 22 | n. 38 | 2017 | p. 154-163 DOI: http://dx.doi.org/10.15448/1980-3710.2017.2.29215 Sessões do Imaginário 
Conforme a tradição estabelecida nos estudos culturais e nas ciências da linguagem, a perspectiva do outro como categoria de recorte e demarcação do visível emerge como princípio fundante para a análise de produtos midiáticos. Tomando-o como um oposto-complementar da identidade, consideramos as narrativas de alteridade como formatos transversais, que propõem a experiência do outro a partir de estratégias discursivas em diversos gêneros.

Partindo de tal pressuposto, pode-se mapear nos textos midiáticos inúmeros esforços de compreensão, tradução e leitura de universos sociocultural ou geograficamente distantes. As narrativas jornalísticas, por exemplo, costumeiramente carregam a marca da alteridade ao retratar e dar visibilidade a processos de conflito social e exclusão ou mesmo exibir costumes e culturas - como notamos em pesquisas anteriores sobre a figuração do outro em grandes reportagens e no jornalismo internacional (Lobato, 2017).

No mesmo rumo, a ficção seriada, com suas tramas ambientadas em outros países, viagens e personagens estrangeiros, promove deslocamentos ao tomar a alteridade como intriga central da narrativa, construindo viagens simbólicas que "mobilizam, deslocam, põem em circulação tanto as pessoas físicas quanto as representações simbólicas" (Buonanno, 2004, p. 334). É também a direção seguida pelas séries televisivas, com suas representações voltadas à constituição de imaginários da semelhança e da diferença em diferentes culturas - como se nota, por exemplo, no estudo de Victoria Johnson (2008) sobre a TV norte-americana.

São enfoques variados, para gêneros midiáticos igualmente diversos em seus estatutos e conexões com o real, que demonstram as possibilidades de enunciação de alteridade no mundo contemporâneo.
Caminhos estes que se conectam àquilo que Soares (2015) descreve como um novo regime de visibilidade, presente nas mídias audiovisuais, que aposta em um realismo associado à evidenciação dos discursos da diferença, à exposição dos desajustes e à desconstrução de posições de sujeitos. Diz-nos a autora:

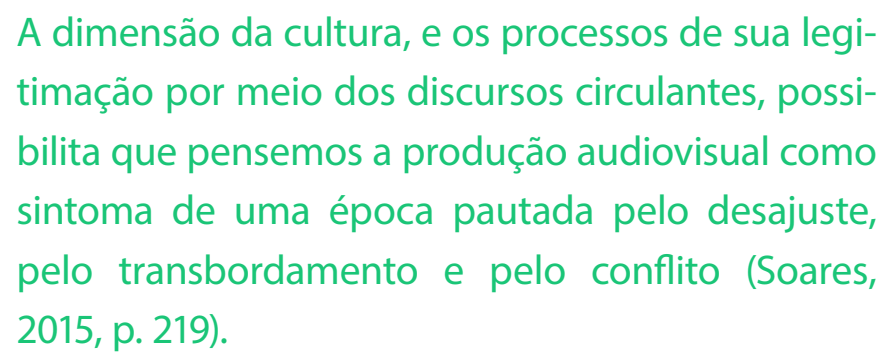

Somos levados, assim, a questionar a dimensão "política" das imagens do outro que costumeiramente irrompem no audiovisual de não ficção em tempos atuais: qual seu potencial de promover engajamento e mobilização em torno de questões de alta relevância na agenda pública, por meio de uma retórica realística-sensível e de uma leitura singular, testemunhal dos fatos? Mais especificamente: quais as implicações éticas desse complexo processo de mediação (Silverstone, 2002)?

A partir de tais provocações, este trabalho lança luz sobre a mediação proposta pela narrativa de Fogo no Mar (Fuocoammare, Gianfranco Rosi, 2016). Centrado nos impactos da onda recorde de refugiados do Oriente Médio e da África, o documentário é ambientado na ilha de Lampedusa, Itália, e adota a perspectiva de um pré-adolescente para tratar da crise humanitária e de seus efeitos sobre os territórios do Mediterrâneo.

A narrativa, dotada de forte ênfase testemunhal, alude ao embate entre identidade e alteridade fundado na construção de polos opositivos, evidenciando rotas enunciativas que colocam o outro em primeiro lugar e destacam a tensão entre o próximo e o distante em um plano material - o das imigrações causadas por tragédias humanitárias, sintomas do contemporâneo que desafiam concepções identitárias e marcações, físicas ou simbólicas, de fronteiras entre o eu/nós e o outro.

\section{Representação, alteridade e suas}

\section{fronteiras: nos limites da mediação}

Os estudos da linguagem e da cultura constroem um raciocínio essencial ao debate sobre os modos com que identidades são erguidas e revisitadas por meio de processos de representação. Perspectivas diversas, como as de Hall $(2001,2016)$, Woodward (2000) e Gomes (2008), contribuem para lançar luz sobre a questão e evidenciar os diversos impactos da representação e da linguagem sobre a própria experiência de mundo.

Stuart Hall, em "Cultura e representação", demonstra três perspectivas sobre tal processo: a primeira, de caráter reflexivo, é aquela que, de modo um tanto essencialista, supõe um caráter de imitação de uma verdade já existente no mundo, ou seja, de que cabe a todo tipo de representação linguística operar em lógica especular. A segunda, uma "abordagem intencional", suporia que o autor "impõe seu único sentido no mundo, pela linguagem" - uma perspectiva também considerada equivocada pelo autor, já que "cada um de nós não pode ser a única fonte de significados na linguagem" (Hall, 2016, p. 48):

A essência da linguagem [...] é a comunicação, e essa, por sua vez, depende de convenções linguísticas e códigos compartilhados. A linguagem nunca pode ser um jogo inteiramente privado. Nossos sentidos particularmente intencionados, ainda que 
pessoais, têm que entrar nas regras, códigos e convenções da linguagem para serem compartilhados e entendidos. A linguagem é um sistema social por completo. Isso significa que nossos pensamentos privados precisam negociar com todos os sentidos das palavras ou imagens guardadas na linguagem que o uso do nosso sistema inevitavelmente desencadeará (Hall, 2016, p. 48).

Assim, o autor conduz seu raciocínio a um terceiro modo de abordar a questão: a ideia de que nem as coisas do mundo em si, nem os sujeitos em forma isolada são capazes de fixar sentidos, já que este processo é construído a partir de "sistemas representacionais". Essa abordagem construtivista, por nós assumida neste trabalho, supõe uma relação entre representações, processos sociais e a construção de rotinas de significação.

Com a noção de "ordem simbólica", Gomes reitera tal raciocínio ao afirmar que esta é produto do trabaIho de "organizar o mundo dizendo-nos, ao diferenciar suas partes, como ele pode ou deve ser visto. A partir disso, delineiam-se linhas de conduta, tomadas estratégicas diante desta visão" (Gomes, 2008, p. 26). Segundo a autora, "a ordem simbólica nos apresenta aquilo a ser visto, experimentado, vivido: tanto os modos quanto as existências. O resto é silêncio" (Gomes, 2008, p. 26).

Essa reflexão possui conexão direta com a marcação de fronteiras e lugares para a identidade e a(s) alteridade(s). Ao trabalhar a ideia de que a linguagem é essencialmente um sistema classificatório, de definição e atribuição de termos, conceitos e significados aos objetos materiais de nossa experiência, a autora reforça que "toda classificação automaticamente hierarquiza pela colocação de pontos chaves, pela divisão que gera subdivisões, pelo estabelecimento de relações" (Gomes, 2008, p. 93).

É essa a dinâmica que encontramos nas marcações de identidade, produzidas essencialmente por meio do narrar - as célebres "narrativas da nação" dos estudos culturais - e da atribuição de sentidos àquilo que convencionamos denominar familiar. Um processo que, por lógica e por oposição (ou exclusão) ao "diferente" ou "exógeno", gera um conjunto de sujeitos e agrupamentos identitários que está além das fronteiras da familiaridade e, por isso, é delimitado como outro.

Por meio da partilha de códigos e valores, estabelece-se um universo de familiaridade, que, segundo Kathryn Woodward (2000), mobiliza relações de poder ao definir quem é incluído e quem é excluído deste sistema; afinal, como implicação lógica, o outro se torna desviante em relação a um universo comum de significações e interesses. A mesma ideia é defendida por Gomes: "esse processo se dá pela forma de ameaça que os outsiders representam aos costumes há muito praticados, às hierarquias já estabelecidas" (Gomes, 2008, p. 73).

A esse raciocínio, cabe acrescentarmos ainda que não só a oposição entre o familiar e o não familiar é traçada de modo relativamente arbitrário como também a própria ideia de um Eu/Nós coeso cai por terra, dada a complexidade da noção de outro. Nesse sentido, Homi Bhabha (1998) afirma que a alteridade pode, e "tende a", emergir de dentro do próprio campo social, expondo processos hegemônicos e contra-hegemônicos nas representações de uma cultura. Por isso, a própria ideia de "povo-como-um" é quebrada pela emergência das chamadas "contra-narrativas" - leituras diferenciadas de uma cultura, por vezes subalterna, que não alcança lugar privilegiado nas representações identitárias de um grupo. Nas palavras do autor:

A fronteira que assinala a individualidade da nação interrompe o tempo autogerador da produção nacional e desestabiliza o significado do povo como homogêneo. O problema não é simplesmente a 'individualidade' da nação em oposição à alteridade de outras nações. Estamos diante da nação dividida no interior dela própria, articulando a heterogeneidade de sua população (Bhabha, 1998, p. 209).

Se esses processos já ocorrem de maneira permanente quando tratamos das relações e entre comunidades e grupos, a questão se torna ainda mais crítica diante dos fluxos da comunicação contemporânea que evocam outra noção pertinente a este trabalho: a de "mediação".

O lugar da "mediação" no jogo das identidades é questão evidente para o estudo das culturas em um mundo fluido e globalizado em termos de experiências e representações. Entendido de diferentes maneiras (Martín-Barbero, 1997; Silverstone, 2002), o conceito deve ser lido de maneira complexa, demonstrando a natureza de processos de interação ocupados por sujeitos com diferentes posições e responsabilidades - dentre as quais se destaca, em nossa investigação, a de falar "por outro, em nome de outro, para outro". Por analisar as implicações e os efeitos sociais e políticos da mediação, com foco nas mídias contemporâneas, a perspectiva de Roger Silverstone (2002) nos parece fundamental.

Propondo um olhar das dimensões social e tecnológica da mediação, o autor demonstra que esta é um processo dialético, protagonizado pelos sujeitos e pelos meios de comunicação que permitem a circulação de 
símbolos na vida social (Silverstone, 2002). A superação da comunicação interpessoal pelas mídias contemporâneas, demonstra $o$ autor, eleva a outro patamar a necessidade de reconhecermos a ampliação de experiências, as potencialidades e também o risco de deformação dos sentidos culturais nas representações que acessamos sobre aquilo que nem sempre conhecemos de forma direta. Se, por um lado, é fato que dependemos cada vez mais da mediação técnica para acessar a realidade, por outro também dispomos de cada vez mais instâncias de mediação que se cruzam para gerar leituras plurais, que não dependem apenas dos processos tecnológicos. Como diz o autor, uma ênfase excessiva nas mídias de massa e seus efeitos "pode ocultar o engajamento contínuo, eventualmente criativo, que as audiências e os espectadores desenvolvem com os produtos da comunicação de massa" (Silverstone, 2002, p. 3, tradução nossa)2. A presença determinante das mídias na vida e na construção da experiência coletiva, no entanto, não deve ser ignorada; por isso, delas devemos exigir cuidado e habilidade à hora de se falar do outro, o que reveste a mediação contemporânea de um compromisso ético latente. Empatia, capacidade de observação e leitura, abertura ao reconhecimento e confiança seriam, nesse sentido, elementos indispensáveis para o exercício de mediações adequadas entre as pessoas e o mundo, em especial o mundo do outro.

\section{O realismo, o real, a materialidade do}

outro: visibilidades complexas

Também é pertinente refletirmos a respeito de um aspecto fundante das narrativas contemporâneas: sua conexão com uma proposta de dar visibilidade e ênfase e, em última instância, enunciar de modo complexo os universos socioculturais, expondo uma dimensão política e estética dos processos de representação. A perspectiva de que o realismo, de maneira exitosa ou não, atravessa as lógicas do texto audiovisual de não ficção nos leva aos estudos da imagem, além das discussões contemporâneas sobre as formas de dar a ver nas mídias.

Conforme indicam autores como Kamper (2001) e Régis Debray (1993), a linguagem visual exerceu diferentes impactos sobre as sociedades ao longo do tempo, indo desde uma função "mágica", de materializar ou seja, tornar o ausente presente - até os modernos processos de simulação por dispositivos digitais. Independentemente da ênfase dada a cada produção, em cada gênero ou suporte, pode-se entender que no visual se está diante de um código ambíguo: “[...] 'imagem' significa, entre outras coisas, presença, representação e simulação de uma coisa ausente" (Kamper, 2001, p. 12). Representação não especular, de enorme poder afetivo, que difere da linguagem do texto por sua polissemia, ambiguidade e potência enunciativa. É o que também nos sinaliza Debray, examinando o poder viral das imagens:

A imagem é mais contagiosa, mais viral do que o escrito. Mas, além de suas virtudes reconhecidas na propagação das sacralidades [...], ela tem o dom capital de consolidar a comunidade crente pela identificação dos membros à Imago central do grupo. Não há massas organizadas sem suportes visuais de adesão (Debray, 1993, p. 91).

A discussão proposta pelos autores nos lança uma possibilidade fundamental para a análise de documentários como Fogo no Mar a de se utilizar a força afetiva das imagens para propor novas experiências de contato, conflito, confronto e choque com o real, baseadas no apelo perceptivo e no poder simultâneo de exibir seus elementos, ressignificá-los e aludir a um contato direto com eles.

Essa perspectiva é defendida por Soares (2015) em um estudo que observa, no campo da televisão, traços de um novo tipo de realismo, crítico, político e sustentado entre a expressão e a dramatização, independentemente do gênero tratado. Essa tendência de produção contém certa "pregnância das formas narrativas", com ênfase na combinação entre testemunhalidade, dramaticidade e uma angulação temática voltada ao outro e sua tradução. Diz a autora:

Ainda que haja um grande volume de produções televisivas que não colocam essa preocupação em primeiro plano, confirmamos uma tendência já observada no caso da televisão brasileira: a forte presença de temas polêmicos, geralmente de cunho social, chamando ao posicionamento e ao engajamento não apenas de produtores, mas também da audiência (Soares, 2015, p. 234).

Notando os novos regimes de visibilidade e a abordagem de estigmas sociais como marcas do audiovisual contemporâneo, Soares indica que "o outro, qualquer que seja ele, pontua desdobramentos que vão dos não ditos à inclusão consentida para, finalmente, assumir lugar de protagonismo, apontando para momentos de afirmação e identificação" (Soares, 2015, p. 224). Sua presença e sua recorrência no televisivo seriam sintomas de uma era de tensão e revisão de posições discursivas e sociais.

É importante notar que o realismo evidenciado na 
análise de Soares (2015), que abarca produtos de entretenimento factual britânico para TV, dialoga também com estudos que reforçam a dimensão afetiva das produções cinematográficas atuais do campo da ficção, igualmente sob influência de uma lógica de concessão de visibilidade e reforço da experiência sensória (Vieira Jr., 2013). Diferentemente do "efeito de realidade" de Roland Barthes, que em textos da literatura do século XIX propõe uma sensação de "representação pura e simples do real", um "relato nu daquilo que é (ou foi)" que surge como "resistência ao sentido" (Barthes, 1988, p. 187), os "novos realismos" citados por Soares propõem não só uma ênfase em temas polêmicos, mas também uma linguagem que, paradoxalmente, pode levar a um reforço da enunciação e a uma exposição do sensível; um jogo de representação assumido, em suma, consolidando:

Um realismo crítico e político, oscilando entre uma forma documental de expressividade e o melodrama ficcional narrativo. Para além da construção de efeitos de realidade, em que ocorre o mascaramento dos processos de ficcionalização nela implicados, vemos nas narrativas audiovisuais uma espécie de retorno pregnante do real (na forma de choque, paixão ou horror) contrapondo-se ao elogio disperso da ficção (na encenação reiterada do mundo vivido) (Soares, 2015, p. 219).

A ancoragem conceitual de um "retorno do real" toma como base a ideia de que a busca pelo Real ${ }^{3}$ (inalcançável, se assumimos a postura da psicanálise) nos conduz, como realizadores e espectadores de produções narrativas baseadas na imagem, rumo a uma tentativa de confronto com o diferente, o desconhecido, 0 inominável, que costumeiramente resulta em um tipo "escancarado" de representação do vivido. É o que percebe Hal Foster (2014), em estudo que abrange as artes visuais: uma espécie de "super-realismo" marca presença em obras que promovem guinadas ao choque, ênfases no grotesco e exibições do traumático, como ferramenta de reiteração dos lugares de experiência e da relação entre Eu/Nós e Outro.

Linha de raciocínio semelhante, no campo da fotografia, é assumida por Susan Sontag (2004) em seu estudo sobre as imagens de dor. Como diz a autora, "num sistema calcado na máxima reprodução e difusão de imagens, $O$ ato de testemunhar requer a criação de testemunhas brilhantes" (Sontag, 2004, p. 32). É dentro dessa perspectiva que as imagens assumem, para Sontag (2004), uma função relevante: tornar real (ou mais real) assuntos costumeiramente ignorados - o que podemos conectar diretamente aos regimes de visibilidade de nosso tempo.

Por fim, cabe-nos ainda fazer breve referência às reflexões de Josep María Català (2005) e seu estudo sobre o regime das imagens complexas. Preocupado com as implicações da transição de uma cultura da imagem para a chamada cultura visual - fundada em representações dinâmicas, móveis e fugidias -, o autor diz que "pensar na imagem era pensar na estrutura pictórica como emblema, era pensar em um objeto posto entre o autor e seu espectador", era "pensar na imagem como informação, como comunicação, como mensagem" (Català, 2005, p. 43, tradução nossa) 4 .

Esse novo fluxo, diz Català (2005), inaugura um regime perceptivo baseado em um princípio de complexidade. Para ele, não existem mais imagens fechadas: todas transformam, influenciam e remetem em maior medida a outras imagens, em permanente interconexão alimentada pelos meios audiovisuais, como a tele- visão e as plataformas digitais. Em linha com reflexões já traçadas pelos demais autores, aponta-se a multiplicidade como uma marca da cultura visual, com representações cada vez mais variadas para se dar conta da complexidade dos fenômenos, sujeitos e culturas.

Em segundo lugar, o autor destaca a entre-captura, um indicativo da capacidade de influência de cada imagem sobre as construções representacionais mais amplas que a abarcam, em lógica de influência, contaminação e adaptação contínuas. Por fim, chega-se à terceira característica da imagem complexa: a estrutura dissipativa, que se refere à capacidade de cada imagem construir-se, dissipar-se e regenerar-se mutuamente, oscilando entre instabilidade e estabilidade. Notamos que Català (2005) lista, como marcas das imagens complexas, elementos do novo regime de visualidade em que o realismo sensível ocupa lugar central: um olhar menos engessado, mais fluido, instável e complexo, para uma realidade sabidamente impossível de se captar de forma objetiva. É a partir desse ponto de vista que enxergamos Fogo no Mar e sua significação da crise humanitária como um registro, um sintoma de nossos tempos; como uma obra que exibe, problematiza e torna visível os conflitos geopolíticos contemporâneos e seus impactos sobre a vida de pessoas direta ou indiretamente transformadas por eles.

\section{As mediações complexas de} Fogo no Mar

Fogo no Mar (Fuocoammare, Gianfranco Rosi, 2016) lança luz sobre a questão das imigrações e crises humanitárias contemporâneas por meio da demonstração da rotina atual da ilha italiana de Lampedusa, situada entre as costas da África e da Sicília, no Mediterrâneo. Com apenas 20,2 quilômetros quadrados de área e 6,3 mil 
habitantes, a ilha recebeu cerca de 400 mil refugiados nos últimos anos, entre vítimas de perseguição religiosa e de guerras civis de países como Costa do Marfim, Nigéria, Líbia, Eritreia, Somália e Síria.

Expondo de maneira significativa nossa argumentação a respeito das narrativas de alteridade, o documentário toma o outro como intriga; para isso, singulariza-se a tensão entre o próximo e o distante, por meio do jovem morador Samuele, de 12 anos, e por oficiais encarregados do resgate de embarcações no Mediterrâneo, em contraposição aos refugiados.

Fazendo alusão a uma pesquisa anterior (Gomes; Lobato, 2016) que abordou a representação do outro na cobertura jornalística da Primavera Árabe, entendemos que Fogo no Mar é esforço de tradução de uma questão complexa e multifacetada e, em seu modo de comunicar, reforça os entrecruzamentos e diferenciações entre identidades. $O$ esforço de tradução ocorre ao longo da narrativa de maneira sutil, fugindo do viés expositivo/ argumentativo de modelos mais engajados do audiovisual documentário. Alternam-se, essencialmente, cenas de Samuele e sua família executando atividades como refeições, pesca e idas ao médico e sequências dos resgates de refugiados, executados pela guarda italiana.

Nos primeiros quatro minutos da obra, não há qualquer referência explícita à crise humanitária; não são exibidas imagens do Mediterrâneo com as embarcações de refugiados. A ênfase está em Samuele, que brinca entre árvores. $\mathrm{O}$ discurso verbal faz referência à crise humanitária a partir de uma sequência de imagens noturnas em alto mar, com uma embarcação lançando luz sobre as águas. Junto delas, um breve diálogo é exposto: "Quantas pessoas?", pergunta a voz, presumidamente da guarda costeira local, de um lado. A resposta é imediata, em tom de desespero: "250". Na sequência, a equipe de resgate pede a posição da embarcação, ao que o outro lado responde, de maneira exaltada: "Nós Ihe imploramos, por favor. Em nome de Deus!". A cena inicial se desloca para uma senhora que ouve rádio na cozinha de sua casa. O locutor da rádio relata mais um resgate de refugiados no mar. A partir daí, a mesma lógica se repete ao longo de 110 minutos de narrativa: monta-se uma oposição discreta, sutil e perturbadora entre o caráter banal do cotidiano de Samuele e seus familiares e o destino dos refugiados e dos responsáveis por resgatá-los em torno de Lampedusa.

Um primeiro aspecto que salta aos olhos em Fogo no Mar é a ausência de narração em off e seu viés de contemplação, com pouca ou nenhuma intervenção visível da equipe responsável. Esta escolha é corroborada pelo modo de construção da obra, sem roteiro, com base em diálogos e visitas do diretor Gianfranco Rosi às residências e aos centros da guarda costeira. $O$ foco está em diálogos e interações entre personagens, capturados nas atividades cotidianas. Não há exibição de dados, gráficos ou argumentos em relação à questão humanitária vivida na África ou no Oriente Médio; o assunto-intriga é suposto a partir do acompanhamento da leitura de real efetuada pela narrativa.

A proposta do documentário é mais próxima à máxima tradicional do cinema documentário referencial, a de "representar as coisas como ela são" (Nichols, 2005, p. 47), fugindo à lógica de um certo "documentário auto-reflexivo", como aponta Bill Nichols, por mascarar os processos de mediação e propor uma leitura bruta da realidade em questão, sem narradores ou autores visíveis por imagens - embora fortemente supostos pelo olhar que se lança. Essa linha está conectada àquilo que Vieira Jr. (2013) defende em relação a "uma forma de narrar na qual o sensorial é valorizado como dimensão primordial para o estabelecimento de uma experiência estética junto ao espectador" (Vieira Jr., 2013, p. 66): em lugar de se explicar tudo com ações e diálogos, diz o autor, adota-se "um certo tom de ambiguidade visual e textual que permite a apreensão de outros sentidos inerentes à imagem" (Vieira Jr., 2013, p. 66).

Em contraposição à sensorialidade ampla, exacerbada do cinema comercial, diz Vieira Jr., uma estética do fluxo - expressão que empresta de Stéphane Bouquet - propõe valorizar "o aspecto micro em lugar do macro", em "um sugestivo convite à subversão da lógica industrial" que adota "sensorialidade (ou meIhor, multi-sensorialidade) difusa, multiforme, reticular e dispersiva" (Vieira Jr. 2013, p. 67). São os traços que identificamos na linguagem de Fogo no Mar, que, ao invés de uma estética ficcionalizada, com amplo uso de trilha sonora, depoimentos, informações e dados, opta pela bruteza de imagens e interações cotidianas em um contexto de choque, conflito cultural, ameaça à vida e - para os refugiados - horror. Entendemos que é esse o regime por trás das imagens, em um esforço para oferecer ao espectador um "tatear" dos ambientes, paisagens e cenas.

Outra marca da obra é a formação sutil das fronteiras entre identidade e alteridade, por meio de jogos opositivos que enfatizam as diferenças não apenas em costumes, mas também em condições de vida. Algumas cenas têm como ênfase demonstrar os processos de contato entre o povo italiano, residente na ilha, e os refugiados; é o caso do médico Pietro Bartolo, que atua no atendimento aos refugiados e faz um ultrassom em uma paciente grávida, recém-resgatada de uma embarcação.

A alternância de cenas que mostram a vida de Samuele e os processos de resgate e atendimento às víti- 
mas provoca um efeito de sentido análogo: gera choque ao alternar momentos absolutamente banais do garoto e eventos graves na vida dos refugiados. É o caso de uma sequência iniciada aos 45 minutos do filme. Após narrar um dia em que Samuele, em uma analogia à cegueira simbólica do Ocidente quanto à questão humanitária, descobre no médico estar com problemas de visão em um de seus olhos, o documentário mostra um grupo de jovens adultos refugiados fazendo uma oração, uma espécie de catarse gerada pela gratidão de sobreviver. Na prática, nesse momento, dá-se voz ao sujeito tratado como outro para que conte diretamente sua experiência. Diz um dos rapazes, em longo discurso:

Este é o meu testemunho. Não podíamos mais ficar na Nigéria. Muitos estavam morrendo, a maioria foi bombardeada. Nós fomos bombardeados, e fugimos da Nigéria. Fugimos para o deserto, fomos para o Saara e muitos morreram. No deserto do Saara, muitos estavam morrendo. [...] As montanhas não conseguiam nos esconder. O povo não conseguia nos esconder. Então fugimos para o mar. [...] O mar não é uma estrada. Oh, mas hoje estamos vivos. É arriscado para a vida não correr este risco, porque a própria vida é um risco. Ficamos muitas semanas no deserto do Saara. Muitos estavam morrendo de fome, muitos bebiam a própria urina. Tudo para sobreviver. [...] Dissemos, “Deus, não nos deixe morrer no deserto". E chegamos à Líbia, e os líbios não sentiram pena de nós. Não nos salvariam por sermos africanos. E eles nos trancaram em suas prisões. [...] Não havia comida na prisão. Batiam em nós todos os dias, e não havia água. E muitos de nós escaparam. E hoje estamos aqui. Deus nos resgatou. Sem risco, entramos no mar. Se não morremos na prisão líbia, não podíamos morrer no mar. E fomos para o mar, e não morremos (Fuocoammare, 2016).

Narrado de forma enfática em uma sala apertada e repleta de refugiados, em plano fechado que focaliza seu rosto, o testemunho compõe o único momento de didatismo (e um ponto dramático fundamental) na narrativa de Fogo no Mar, mostrando a rota de um grupo de africanos em fuga do terrorismo e de conflitos civis protagonizados por milícias, governos e fundamentalistas religiosos em diversos países. A contraposição à banalidade de um pequeno problema de visão de Samuele nas duas cenas, em especial, demonstra o esforço da obra em construir uma perspectiva crítica sobre a crise humanitária em curso, destacando a rotina banal de Lampedusa e o deslocamento dos que deixaram seus lares e países de origem para uma jornada de privações.

Ainda quanto aos jogos opositivos, deve-se notar que o grupo de imigrantes não é tratado em sua complexidade: como que assumindo o olhar do povo de Lampedusa, quem chega pelas embarcações de resgate é tratado como "um" outro em Fogo no Mar, sem considerar nacionalidades, etnias, religião e outras particularidades que evocam os vários estados-nação de onde vieram. Tal ideia alude às construções "essencialistas" de identidade e alteridade, citadas por Bhabha (1998) e discutidas anteriormente, que buscam - em vão - apagar a multiplicidade de sentidos atribuíveis ao outro.

$\mathrm{O}$ regime de visibilidade proposto pelas imagens é um terceiro aspecto que devemos destacar, por, em nossa perspectiva, propor um uso complexo do campo visual, pautado por um realismo de base sensível-afetiva e sensória que se traduz em registros que transitam entre a linguagem poética e uma extrema referencialidade, orientada ao choque do/pelo real.

Por um lado, há longas digressões sobre a vida de Samuele e suas relações com familiares e com amigos, nas quais as paisagens da paradisíaca Lampedusa dão lugar a registros do anódino, com alternância entre panorâmicos e planos-detalhe de objetos e partes dos corpos humanos, além de exibições do interior de sua casa e da embarcação da família. Embora aparentem banalidade, tais imagens contribuem para uma visualização complexa (Català, 2005), multifacetada, da realidade representada, além de corroborar a produção de polos opositivos por meio da alternância entre o conforto da identidade-Ocidente (em solo, em Lampedusa) e o desconforto e a dor do outro (no mar, em botes ou nas embarcações da guarda costeira).

Quanto às imagens-choque, presentes especialmente a partir da primeira hora do documentário, seu objetivo é claro: expor, por meio de um tipo de realismo sensório (Vieira Jr., 2013) e sensível que se revela engajado sem perder o tom observativo, a grave situação dos que conseguem chegar a Lampedusa após o resgate costeiro. Se, como diz Foster (2014, p. 174), "no super-realismo a realidade é apresentada como sobrecarregada de aparência", em Fogo no Mar a realidade extrema se traduz em imagens de corpos, cadáveres ou vivos, marcados pela doença, pela desnutrição e por queimaduras e cicatrizes.

O recurso marca presença em um dos poucos depoimentos direcionados ao narrador. Enquanto observa uma tela de computador, na qual exibe imagens de refugiados logo após um resgate, o médico Pietro Bartolo - o mesmo filmado enquanto fazia ultrassom em uma paciente grávida - narra sua experiência ao lidar com traumas, ferimentos e doenças graves dos refugia- 
dos que chegam à pequena ilha. O tom empático e a perspectiva crítica quanto à situação são transmitidos por meio de seu testemunho, que opera como uma convocação ou discurso imperativo dentro de uma narrativa de tons aparentemente neutros:

Havia 840 neste barco. Estes eram... os da "primeira classe". São os da primeira classe. Ficavam fora. Pagaram US\$1.500. Estes eram os da "segunda classe", aqui no meio. Pagaram US\$1.000. E aí, eu não sabia disso, no porão havia muitíssimos que pagaram US\$ 800. Eram a "terceira classe". Quando os peguei na costa, eles não tinham fim. Não acabavam. Centenas de mulheres e crianças. Estavam muito mal, especialmente os do porão. Estavam navegando havia sete dias. Desidratados, malnutridos, exaustos. Eu trouxe 68 para a sala de emergência. Estavam muito mal. [...] É dever de todo ser humano, que seja humano, ajudar essas pessoas. Quando conseguimos, ficamos muito contentes, ficamos felizes... por ter podido ajudar. Às vezes, infelizmente, não é possível. Tenho que testemunhar coisas terríveis, horrorosas: mortos, crianças... Nessas ocasiões, sou forçado a fazer o que mais odeio, que é inspeção cadavérica. Tenho feito muitas, talvez até demais (Fuocoammare, 2016).

Em seu encerramento, após 1h40, o filme exibe sua sequência mais forte: um resgate em que refugiados desidratados, muitos em estado de choque ou semiconscientes, são trazidos a um barco da guarda costeira e ficam estirados no chão, sem conseguir reagir ou responder às equipes de resgate. Dando sequência a registros panorâmicos do barco lotado de refugiados e

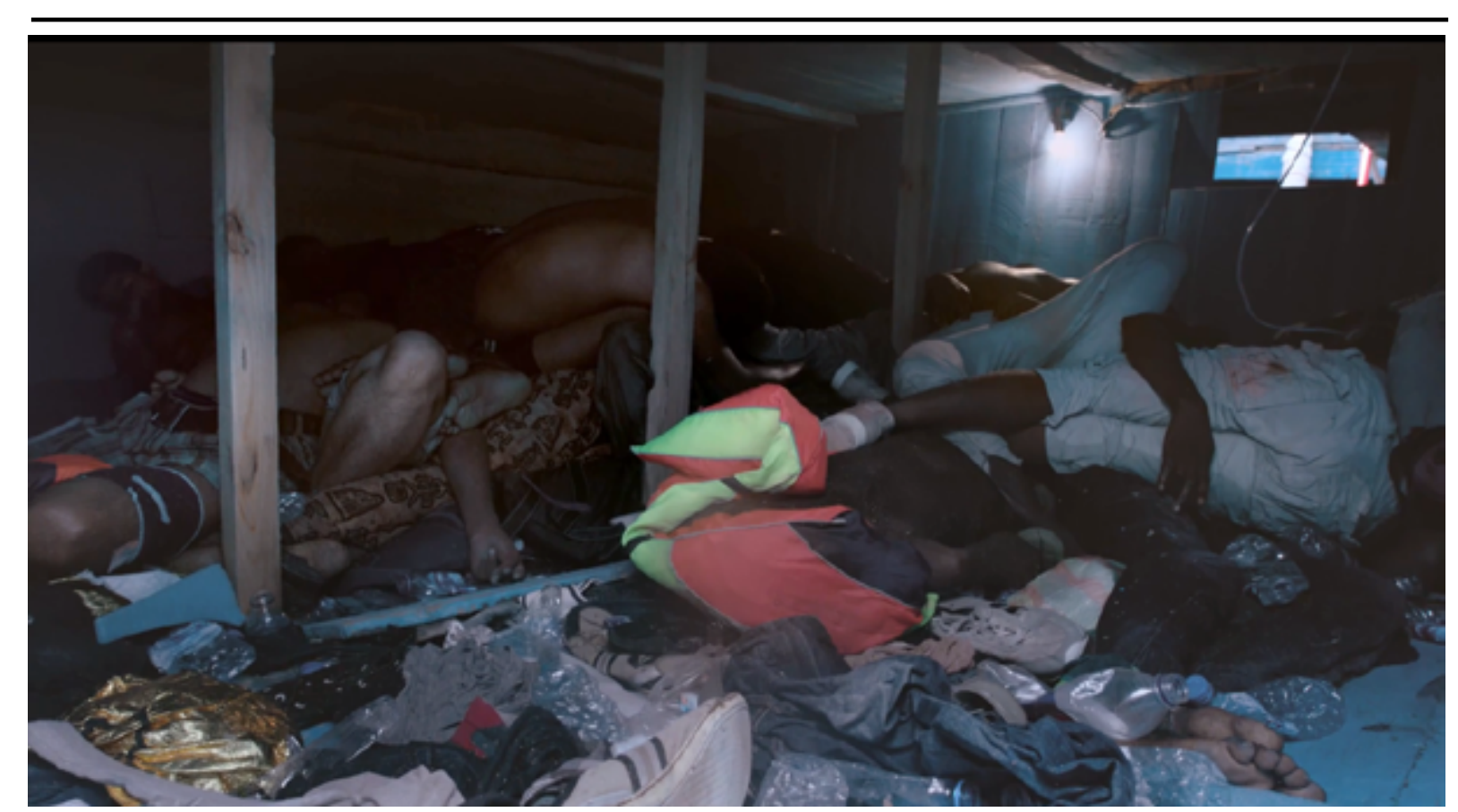

Figuras 1 e 2: Imagens do resgate da embarcação, na qual são encontrados vários corpos. Fonte: Gianfranco Rosi (2016).

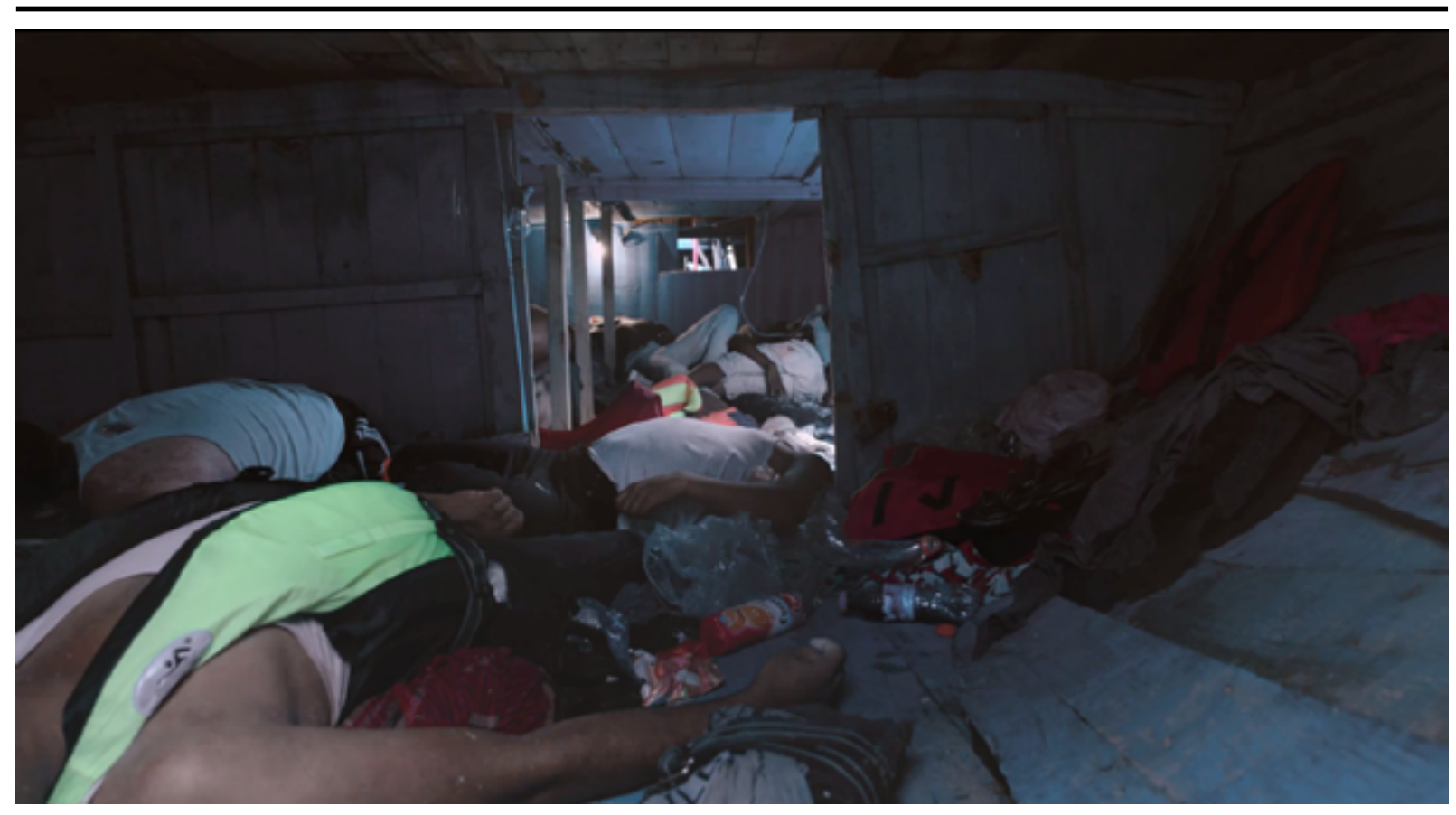

161 PORTO ALEGRE | v. $22 \mid$ n. 38 | 2017| p. 154-163 Sessões do Imaginário 
de rápido exame de um deles, que aparenta desorientação, são exibidas imagens das equipes resgatando corpos. Mais oficiais da guarda costeira se dirigem ao bote. Um rapaz não identificado explica, com voz embargada: "No barco há dois níveis, um em cima e o porão. No porão é muito, muito quente. Não há ar. É muito quente. Por causa disso, mais pessoas..." (Fuocoammare, 2016). E gesticula, aludindo à morte. Fogo no Mar recorre, então, à exibição da dor com imagens de corpos jogados dentro do casco da embarcação; pessoas que não resistiram à fome, à sede, ao calor, à viagem.

À cena, que como o restante do documentário conta apenas com som ambiente ou o próprio silêncio, segue-se mais uma sequência com Samuele, brincando na mata com uma lanterna, além de uma senhora que arruma sua cama e o locutor da rádio local, que olha para seu microfone no estúdio, com expressão de pesar. A narrativa se encerra com Samuele sentado no píer da pequena ilha, observando o mar.

Ao contrário do que outra lente de análise poderia supor, não identificamos no documentário qualquer espetacularização da morte; aqui, a imagem-choque possui a clara função de despertar sensibilidade, algo que Sontag (2004) atribui em seu estudo à fotografia de guerra. De um lado, a iluminação irregular e a dificuldade em enquadrar os corpos aludem às "visibilidades precárias" que Soares (2015) encontra no realismo sensível televisual contemporâneo. De outro, não há como desconsiderar o impacto gerado pelo caráter estacionário das imagens do interior do barco: são apenas três enquadramentos em trinta segundos, com diferentes ângulos para a pilha de corpos e objetos.

Em linha com Sontag (2004, p. 23), acreditamos no potencial enunciativo desse tipo de registro; para ela, "numa era sobrecarregada de informação, a fotografia oferece um modo rápido de apreender algo e uma forma compacta de memorizá-lo. A foto é como uma citação ou uma máxima ou provérbio". E é assim, como um lento fotografar do que os olhos do Ocidente resistem a ver, que a última cena de Fogo no Mar se fixa à memória, como emblema do horror de tantas mortes indignas.

\section{Considerações finais}

Cientes do trabalho complexo que envolve a mediação de outro(s) extremamente complexo(s), como é o caso da atual crise humanitária vigente em países assolados por conflitos na África e no Oriente Médio, somos levados a reconhecer em Fogo no Mar algumas das características do que Roger Silverstone denomina uma ética da mediação. Para o autor, os processos de mediação contemporâneos são marcados pela polissemia - ou seja, multiplicidade de significados -; pela corporalidade e sociabilidade, por sua conexão direta com os indivíduos e comunidades participantes de uma relação mediada; e pela ética, que se materializa no cuidado à hora de falar do outro. É preciso, reforça o autor, construir "um senso do outro suficiente não apenas para a reciprocidade, mas também para gerar um senso de cuidado, obrigação e responsabilidade" (Silverstone, 2002, p. 14).

A construção de Fogo no Mar, por uma série de escolhas que abrangem a complexidade das imagens e dos modos de representar, o uso da imagem-choque e a representação de polos opositivos, demonstra um exercício daquilo que Silverstone (2002) denomina proper distance: ou seja, um distanciamento suficiente para uma postura respeitosa para com a alteridade, sem apagá-la ou distorcê-la, mas ao mesmo tempo capaz de capturar seus elementos-chave. Isso se manifesta tanto na linguagem verbal - presente nos depoimentos e diálogos, raros e utilizados somente com função diegética evidente - quanto no regime das imagens, marcadas pela complexidade (Català, 2005) em suas dimensões de multiplicidade e entre-captura.

Identificamos que a leitura de real efetuada na obra exercita um outro tipo de realismo, de base sensível e sensorial. É por meio do acesso à realidade proposto por obras do cinema contemporâneo que podemos "observar o tensionamento que se faz junto à experiência da contemporaneidade em cada contexto" (Vieira Jr., 2013, p. 77), em um diálogo estético-ético-político que conectamos à dimensão formativa da narrativa de alteridade - capaz de nos convidar a decifrar, ler, compreender e por fim reconhecer o outro em sua plenitude por meio de uma intriga associada à diferença cultural. Em Fogo no Mar, mesmo que sem o engajamento evidente de outros documentários sobre as crises humanitárias do século XXI, a ética da mediação está presente com uma enunciação baseada na construção de empatia, com clara ancoragem sociopolítica e preocupação nos modos de dar a ver o(s) outro(s).

\section{Referências}

BARTHES, Roland. O efeito de realidade. In: BARTHES, Roland. O rumor da língua. São Paulo: Brasiliense, 1988.

BHABHA, Homi. O local da cultura. Belo Horizonte: UFMG, 1998.

BUONANNO, M. Além da proximidade cultural: não contra a identidade, mas a favor da alteridade. In: LOPES, Maria Immacolata (Org.). Telenovela, internacio- 
nalização e interculturalidade. São Paulo: Loyola, toras Apicuri/PUC-Rio, 2016.

2004.

CATALÀ, Josep María. La imagen compleja. Bellaterra: UAB, 2005.

DEBRAY, Régis. Vida e morte da imagem. Petrópolis: Vozes, 1993.

FOSTER, Hal. $O$ retorno do real. São Paulo: Cosac Naify, 2014.

GOMES, Mayra Rodrigues. Comunicação e identificação: ressonâncias no jornalismo. Cotia: Ateliê, 2008.

GOMES, Mayra Rodrigues; LOBATO, José Augusto Mendes. A Primavera Árabe e o enquadramento do outro: a captação da alteridade na narrativa jornalística. In: JESUS, Eduardo; TRINDADE, Eneus; JANOTTI JR., Jeder; ROXO, Marco (orgs.). Reinvenção Comunicacional da Política: modos de habitar e desabitar o século XXI. Livro Compós 2016. Salvador/Brasília: EDUFBA/Compós, 2016.

LOBATO, José Augusto Mendes. A alteridade na ficção seriada e na grande reportagem: um estudo sobre as estratégias de representação do outro na narrativa televisual brasileira. Tese (Doutorado em Teoria e Pesquisa em Comunicação) - Escola de Comunicações e Artes, Universidade de São Paulo, São Paulo, 2017.

HALL, Stuart. A identidade cultural na pós-modernidade. Rio de Janeiro: Guaracira, 2001.

Cultura e representação. Rio de Janeiro: Edi-
JOHNSON, Victoria. Heartland TV: prime-time television and the struggle for national identity. New York City: NYU Press, 2008

KAMPER, Dietmar. Imagem. In: WULF, Chistoph; BORSA$\mathrm{RI}$ A. (Orgs.). Cosmo, corpo, cultura. Milano: Mondadori, 2001.

MARTÍN-BARBERO, Jesús. Dos meios às mediações. Rio de Janeiro: Ed. UFRJ, 1997.

NICHOLS, Bill. A voz do documentário. In: RAMOS, F. (Org.). Teoria contemporânea do cinema. São Paulo: Editora Senac, 2005

SILVERSTONE, Roger. Complicity and collusion in the mediation of everyday life. New Literary History, v. 33, n. 4, p. 761-780, 2002.

SOARES, Rosana de Lima. Realismos audiovisuais: visibilidades intertextuais em documentários televisivos. Revista Doc On-line, Universidade da Beira Interior (Portugal), Universidade Estadual de Campinas (Brasil), n. 18, p. 216-240, set. 2015.

SONTAG, Susan. Diante da dor dos outros. São Paulo: Companhia das Letras, 2004.

VIEIRA JR., Erly. Sobre a dimensão transcultural do realismo sensório no cinema mundial contemporânea. In: BRANDÃO, A.; CORSEUIL, A.; LIRA, R. (Orgs.). Cinema, globalização, transculturalidade. Palhoça: Unisul/Socine, 2013.
WOODWARD, Kathryn. Identidade e diferença: uma introdução teórica e conceitual. In: SILVA, Tomaz. Identidade e diferença. Petrópolis: Vozes, 2000.

\section{Referências audiovisuais}

ROSI, Gianfranco. Fuocoammare. [Documentário]. Produção de Gianfranco Rosi et al., direção de Gianfranco Rosi. Itália/França, Stemal Entertainment, Instituto Luce Cinecittà, 2016. 114min. color. son.

\section{Notas}

1 Doutor em Ciências da Comunicação pela Universidade de São Paulo (2017). Mestre em Comunicação na Contemporaneidade pela Faculdade Cásper Líbero (2011). (Report Sustentabilidade: Rua Dráusio, 484. Butantã. Cep: 05511010 - São Paulo, SP - Brasil) E-mail: gutomlobato@gmail.com.

2 No original: "[such privileging] would miss the continuous and often creative engagement that listeners and viewers have with the products of mass communication".

3 Real é segundo a acepção lacaniana, também vinculada ao pensamento de Hal Foster $(2001 ; 2016)$.

4 No original: "pensar en la imagen era pensar en la estructura pictórica como emblema, era pensar en un objeto interpuesto entre el autor y su espectador (...), era pensar en la imagen como información, como comunicación, como mensaje". 